\title{
NOTAS DE UM ESTÁGIO NO MÉXICO
}

\author{
ERNESTO PATERNIANI \\ Assistente da Secção de Genética
}

\section{INDICE}

o que é o programa agrícola mexicano . . . . . . . . . . 286

Estações Experimentais .. . . . . . . . . . . . . . . . . . 287

o programa de pesquisa . . . . . . . . . . . . . . . . . . . 288

Problemas do melhoramento do milho no México .. . . . . . . 289

Métodos de melhoramento empregados e resultados obtidos .. .. 291

Bibliografia .. . . . . . . . . . . . . . . . . . . . . . . 294 
As presentes notas são referentes a um estágio realizado pelo relator das mesmas, no Programa Agrícola Mexicano, no que diz respeito a melhoramento de milho, durante o períodc compreendido de Março de 1951 a Março de 1952.

\section{O QUE E O PROGRAMA AGRICOLA MEXICANO}

Em fevereiro de 1943 nasceu um dos mais notáveis projetos de cooperacão internacional : o Programa Agrícola Mexicano. Após um período de estudo e planejamento por parte de técnicos norte-ámericanos, e um posterior convite do govêrno mexicano à. Fundação Rockefeller para levar a cabo um plano cooperativo de reerguimento da agricultura, estabeleceu-se o Programa em questão, como uma empreza conjunta da Fundação Rockefeller e da Secretaria de Agricultura e Pecuária (*). $\mathrm{E}$, pela primeira vez na história daquela filantrópica organização, foram enviados especialistas em agricultura a um país estrangeiro para trabalhar conjuntamente com os técnicos dêsse país e elevar o nível da agricultura nacional.

Foi tão oportuna quanto necessária a instalação dêsse Programa, uma vez que já constituia sério problema mexicano a produção de víveres, a qual vinha decrescendo assustadoramente. Acrescente-se ainda o fato de que apenas cêrca de $8 \%$ da superfície territorial do México corresponde a terras de cultivo e que 4/5 destas, são classificadas como terras semi-áridas e ter-se-á, então uma idéia de quanto era urgente uma sólida campanha de reerguimento agrícola.

F' interessante salientar alguns dos princípios básicos que foram estabelecidos para servir de guia nos trabalhos de colaboração :

1) Nenhuma pessoa fará parte do pessoal da Fundação Rockefeller destinado a êsses trabalhos, que não seja considerada como de primeira categoria de acôrdo com as normas americanas.

2) Nenhuma pessoa será efetivada, a menos que esteja disspasta a seguir em forma permanente uma carreira de investi-

(*) A Secretaria de Agricultura e Pecuária é um órgão federal e corresponde ao nosso Ministério da Agricultura. 
gaçãu agricola no estrangeiro. A seleção feita sob êste critério: revelou-se excepcionalmente efetiva.

3) O pessoal da Fundação Rockefeller, assim como os seus colegas mexicanos estão organizados num departamento do govêrno de carater semi-oficial : que é parte integrante da Secretaria de Agricultura e Pecuária porém, que possui um alto grau de autonomia.

O programa goza, assim, das vantagens de estar dentro da estrutura do Govêrno Mexicano e, ao mesmo tempo de evitar a complicada máquina burocrática que sempre acompanha a papelada oficial.

4) Os resultados obtidos de reconhecido valor são utilizadoss com a maior brevidade possível. Não se espera obter o milho ou o trigo "perfeito" mas, qualquer melhora é logo amplamente aproveitada.

5) Um relevante aspecto do Programa é o intenso treinamento de jovens agrônomos mexicanos para formar um grupo de investigadores capazes que eventualmente possam tomar a resprnsabilidade de um programa técnico de agricultura.

O Programa tem, como se vê, uma finalidade dupla : o reerguimento efetivo da agricultura e o adextramento de jovens técnicos inexicanos.

O êxito alcançado foi completo em tôdas as finalidades e, isso claramente será constatado atravez dos fatos expostos.

\section{ESTAÇÕES EXPERIMENTAIS}

Inúmeros são os campos experimentais mantidos pelo Programa em quasi tôda a República Mexicana. A multiplicidade dêsses campos se faz necessária principalmente pela grande diversidade de climas e também pelos problemas de melhoramento particulares de cada regiäo. Aliás, a experiência já mostrou que, real eficiéncia no melhoramento só se obtém quando se selecioni o material cultivado na região para a qual é destinado. Sempre é duvidosa uma seleção feita em clima diverso daquele onde deve ser empregado o cultivo em questão.

Para compreender a distribuição das estações experimentais, é conveniente ter uma idéia dos principais tipos de clima do México. Assim, basicamente, pode-se distinguir pelo menos os três seguintes tipos de clima bem diferentes que ocorrem na 
parte central da República, que é a região onde mais ativos têrn sido os trabalhos do Programa :

1 - Mesa Central, com mais ou menos $2.200 \mathrm{~m}$ de altitude.

2 -- "El Baijo" com 1.500 a $1.800 \mathrm{~m}$ de altitude.

Em ambas as regiões o clima é relativamente sêco, com apenas trés ou quatro mêses de chuva, podendo, também, ocorrer anos mais extremadamente secos.

3 - Zonas chamadas de "Tierra Caliente" ou tropical, próximas do nivel do mar, que se caracterizam por muito calor e umidade

Para c programa da Mesa Central, funciona o campo de Chapingo anexo à Escola de Agricultura e, o primeiro a ser estabelecido Situa-se o referido campo a $40 \mathrm{~km}$ da cidade do Méxic pois, conta com bem montados laboratórios, câmara frigorífica para a conservação de sementes, máquina secadora de grăos em geral, espaçosa estufa de vidro e galpão para máquinas agrícolas

No Estado de Morelos funciona outro campo, que é dos mais ativos no melhoramento do milho. Localizado a $1200 \mathrm{~m}$ de altitude, goza da grande vantagem de permitir o cultivo do milho duas vêzes ao ano - no verão e no inverno.

A par dêsses dois campos base do Programa, inúmeros oultrus, de trabalho menos intenso, estão espalhados pela República e, cuja principal finalidade é a de ensaiar os tipos novos obtidos. Estes campos estão situados principalmente na região de "El Bajio", principal produtora de milho e, nas regiões tropicais conhecidas por “Tierra Caliente". Recentemente, o Programa está abrangendo outras regiões, ampliando cada vez mais o seu campo de ação.

\section{O PROGRAMA DE PESQUISA}

Atendendo às necessidades mais prementes da agricultura mexicana, foi estabelecida a seguinte ordem de trabalho: 1) solos, 2) melhoramento (fitotecnia), 3) contrôle de enfermidades e pragas e, 4) pecuária. Dêstes, apenas os trabalhos com pecuária não foram ainda iniciados. 
A parte de melhoramento do milho será tratada com mais detalhe, em virtude da natureza do estágio que se prendeu a esta especiaindade.

1) Solos: Os solos do México são, em grande parte de natureza vulcânica. Este fato imprime umas tantas características sendu a principal, o grande teôr de potássio encontrado nos mesmos

Nesta Secção do Programa, inicialmente foram feitas análises para determinar as características físicas e químicas dos solıs das principais regiōes agrícolas de México e, para conhecer as necessidádes em matéria orgânica e elementos minerais Com base nas informações obtidas, fizeram-se ensáios com fertilizantes para determinar as melhores fórmulas de adubação e métodos de aplicação. Em vista da geral carência de matéria orgânica e nitrogênio dos solos, foi dada, também, especial atenção à adubação verde, sendo que neste particular encontraram.se algumas leguminosas de real valor. Uma das mais notáveis é conhecida com o nome de "Trebol Huban".

\section{2) Fitotecnin}

2a - Milho: No melhoramento dêsta gramínea está concentrada a maior parte da atividade do Programa Agrícola Mexicano, o que é perfeitamente compreensivel pois, é êste cereal o alimento básico do México. $O$ mexicano, pràticamente vive de milho Em tódas as refeições entra o milho em uma ou mais das inúmeras preparações que com êle se fazem. Estima-se que o mexican consome, em média, 250 gramas de milho por dia. Não é para surpreender pois, que cêrca de $60 \%$ das terras cultivadas do México são ocupadas pelo milho. Planta-se milho em tôdas as iatitudes do país e, desde o nível do mar até 3.000 metros de altitude.

\section{PROBLEMAS DO MELHORAMENTO DO MILHO NO MÉXICO}

1) Sendic o México um país de grande diversidade de climas e, cultivando-se o milho em tôdos êles, tem-se aí já um problema de real importância : a obtenção de tipos melhorados e bem adaptados a cada uma das regiões climáticas. 
2) Devido ao curto período de chuvas nas principais zonas de cultivc do milho, encontram-se duas modalidades bem distintas de cultura : milho cultivado com irrigação (maiz de riego) e milho cultivado sem irrigação (maíz de temporal).

O milho irrigado é semeado cêrca de 2 a 3 meses antes do início das chuvas e é bastante tardio, pois, em geral tem um ciclo de 4 a 6 meses o que lhe permite um rendimento bastante elevado.

O milho não irrigado é semeado em junho quando se iniciam as chuvas e deve ser precóce para completar o ciclo nos poucos meses de chuva.Êste milho tem, forçosamente um rendimento bem menor que o anterior.

Essas duas modalidades de cultivo referem-se às regióes da Mesa Central e de "El Bajio" pois, nas regiões tropicais "tierra caliente" a distribuição das chuvas é bem mais sa!isfatória.

3) Para a região de "El Bajio" é serio o problema da resistência à seca para o milho não irrigado pois, há anos que não tão extremadamente secos, em que a produção do milho crioulo nem siouuer compensa a colheita do produto.

4) No referente a enfermidades, estas, em geral não constituem problema muito sério. São mais importantes as seguintes : podridão da espiga causada pelo Fusarium moniliforme Sheld., podridão da raíz causada por vários fungos, ferrugem. produzida pela Puccinia sorghi Schw. e o carvão do milho devidc ao Ustilago zeae (Beckm) Ung.

A podridão da espiga tem certa importância, sobretudo ná regiaão de "El Bajio" e, a ferrugem é na Mesa Central que tem mais importância onde, dificilmente se encontra uma planta que absolutamente não esteja atacada pela $P$. sorghi.

Quanto a pragas, a mais importante é a conhecida por "gusano cogollero del maiz" ou seja Laphygma frugiperda (A. e S.)

5) Unna característica da cultura do milho no México é que após a colheita, tôda a planta sêca (resto de cultura) é retirada do campo e dada aos animais como forragem. Isso faz com que os lavradores deem preferência a plantas de porte mais al.to. E, também é desejável que as plantas ainda estejam verdes após a maturação do milho o que, além de satisfazer a finalidade forrageira indica, ainda, excelente grau de sanidade $\mathrm{dz}$ planta 


\section{MÉTODOS DE MELHORAMENTO EMPREGADOS E RESULTADOS OBTIDOS}

1) Coleção e experimentação das variedades crioulas: Devido à grande multiplicidade de variedades de milho existentes nc México, podia ser obtido um sensível aumento de produção, apenas com a substituição das más variedades pelas me. lhores que fossem encontradas. $E$, esta foi precisamente a primeira iniciativa do Programa no sentido de melhorar a produção de milho, isto é, colecionar o maior número possível de tipos de milho, prová-los em ensáios de rendimento e distribuir os mais promissores. Este trabalho, além de identificar as melhores variedades, possibilita 0 isolamento do material mais promissor para continuar com o programa de melhoramento e, também, a conservação de material genético para uso futuro

Foram assim distribuidas para a Mesa Central e "El Bajio", algumas variedsdes relativamente bem produtivas em substituiçã.) às anterıores e, ainda hoje, para as zonas tropicais, cnde o programa apenas se inicia, é uma variedade melhorada, a V-520C, que é distribuida aos agricultores da região.

2) Elaboração de sintéticos tendo como base as melhores variedades: $\mathrm{O}$ passo seguinte foi o de obter um tipo de milho mais produtivo. procurando combinar as bôas qualidades das melhores variedades. Empregaram-se, então, sintéticos de "top-crosses" como meio mais rápido para atingir o objetivo em vista. O Rocamex VS-101, um das sintéticos obtidos para cultura não irrigada da Mesa Central, foi assim constituido:

Leon 1-24 $x$ Variedade Urquiza

Rucarnex V-21-64 x Variedade Urquiza

Rocamex V-21-5 x Variedade Urquiza.

As sementes obtidas dos cruzamentos controlados, entre os três "top-crosses" acima, em todos os sentidos, foram já plantados no campo para polinização livre.

Esses sintéticos foram feitos unicamente como passo intermediário para atingir o milho híbrido e, portanto, não se encontram mais em distribuição. Entretanto, persiste a idéia de empregar futuramente variedades sintéticas para determinada.s regiões. 
3) Obtenção de híbridos: As variedades mais produtivas encontradas são o material básico inicial para a obtenção de linhagens que serão usadas nos híbridos. $O$ isolamento das $1 \mathrm{i}-$ nhagens $\dot{\epsilon}$, em geral, feito do seguinte modo: autofecundam-se inicialmeiste 500 a 1000 plantas de uma variedade sendo, n. ani) seguinte as sementes de cada espiga obtida, plantadas em parcelas especiais para observação e nova autofecundação.

No Programa Agrícola Mexicano, por vários motivos, senipre se procurou utilizar linhagens com apenas uma autofecundaçã: E Esta particularidade, aliás, constitui a diferença máxima entre èste Programa e os programas clássicos de melhoramento do milho. Assim sendo, procura-se logo testar a capacidade de cornbinação das linhagens S1, cruzando-as com uma variedade (top-iross) e, comparando as combinações obtidas em ensáios de rendimento. Fazem-se, então, cruzamentos entre tôdas as linhagens que se mostraram com bôa capacidade de combinaçã? e, os híbridos simples obtidos são, por sua vez experimentadus em outros ensáios de rendimento. Finalmente, com base: nos rendimentos dos híbridos simples, com relativa facilidade, determinam-se quais são os híbridos simples que, combinados deverão dar o melhor híbrido duplo. Entretanto, apesar da previsão sôbre os híbridos duplos ser bastante satisfátória, sem?pre se incluem alguns ensáios de rendimento de diversos hi.bridos duplos para se obter confirmação adicional sôbre o comportamento dos mesmos. O tipo de plano experimental para $\hat{\epsilon} s-$ ses fins, estandardizado para todo o Programa, é do tipo lattice simples $7 \times 7$.

Diversos híbridos adaptados às principais regiões de cultivo do milho estão em distribuição aos agricultores, como se vode verificar pelos exemplos abaixo:

\section{1) Para a Mesa Central (2.200 $\mathrm{m}$ de altitude)}

a) Para cultura irrigada está em distribuição o Rocamex: H-1 que é um híbrido triplo (three way cross) e, possivelmente o mais eficiente obtido até agora pelo Programa Agrícola Mexicano Suas principais características agronômicas são as se-guintes : produz de 1,2 a 1,3 espigas por planta e tem um rendimento que fàcilmente alcança 8 ton. de milho desgranado por hectare. E' resistente ao acame. Quando semeado para ensilagem $(40 \mathrm{~kg}$ de sementes por hectare) produz 100 ton. de mas. sa pcr hectare. O seu ciclo vegetativo é de 6 meses e, o objetivo no momento é diminuir um pouco êsse período. 
O crioulo correspondente é o Chalco que é inferior ao $\mathrm{R}_{0}$. camex $\mathrm{H}-1$ em tôdas as características apontadas acima.

b) Para cultura não irrigada (siembra de temporal), ainda não se conseguiu um híbrido satisfatório. Distribui-se o Rocamex H-123, sendo o crioulo correspondente o "Maiz Conico".

2) Para "El Bajio" (1.500 a $1.800 \mathrm{~m}$ de altitude).

a) Distribui-se para cultura irrigada o híbrido duplo Rccamex H-311A que é bastante produtivo, muito sadio, porém, muito tardio.

b) Para um cultivo intermediário (temporal mediano) distribui-se o Rocamex H-309A que é um excelente híbrido duplo e o mais apreciado na região. Tem apenas o defeito de ser algo suceptivel à podridão da espiga. Esta característica, que é consequência de uma de suas linhagens, está para ser eliminada, peja substituição da linhagem responsável por outra mais conveniente. $O$ nosso híbrido será então, designado por Rocamex H-309B.

c) Pára cultura não irrigada tem-se o Celita que é formado com linhagens de duas variedades - Celaya e Bolita (razão do seu nome). E' um híbrido triplo precóce e extraordinariamente resistente à seca o que é condição importante para êste tipo de cultura na região em apreço.

Tais são os principais híbridos atualmente em distribuição. Outros existem ainda não devidamente provados, porém, bastante prometedores.

A produção da semente híbrida em grande escala para ser distribuida aos lavradores é feita do seguinte modo: os hibridıs simples produzidos pelo Programa são entregues a $\mathrm{rm}$ órgão oficial - a "Comision del Maiz" - , que faz o cruzamento duplo. Para isto, executa contratos com lavradores que plantam os lotes de despendoamento. A semente híbrida, c.. lhida e convenientemente tratada é, então vendida, pelo mes. mo órgão oficial, aos agricultores. Algumas dificuldades têm, surgido, entretanto, nos últimos anos, na parte de fiscalizaçâo do despendoamento e colheita dêsses campos de cooperação.

Trigo: O melhoramento do trigo é outro campo onde o Programa tem se dedicado com afinco. Embora seguindo a mesma marcha do melhoramento do milho, o principal proble- 
ma na cultura do trigo foi desenvolver variedades resistentes a enfermidades causadas por fungos, notadamente a ferrugarn do trigo Aliás, um programa de melhoramento do trigo é. sempre, em grande parte um programa de fitopatologia.

México sempre cultivou trigo apenas no inverno, embora as varjedades existentes muitas vêzes pouco ou mesmo nada produzissem, devido ao ataque de Puccinia graminis tritic $i$ Erikss. Hoje, entretanto, graças ao notável êxito alcançado pelo Programa Agrícola Mexicano, o país cultiva trigo com absoluto sucesso não só no inverno mas, o que é extraordinátio, também no verão.

Além dos aspectos analisados, o Programa se ocupa também do inelhoramento do feijäo, batatinha, soja, sorgo para grão e, rnais recentemente de hortaliças.

Trabalhando conjuntamente com os melhoristas, fitopatclogus e entomólogos trabalham no contrôle das enfermidades e pragas das plantas.

O Programa Agrícola Mexicano conta, atualmente com o seguinte pessoal técnico à cabeça dos diversos departamentos : Diretor Local, Dr. E. J.Wellhausen; Entomologia, Dr. Douglas Barnes; Fitopatologia, Dr. Norman E. Borlaug; Genética, Dr. L. Sterling Wortman; Solos, Dr. John B. Pitner; Biblioteca, Dr. Dorothy Parker. Além disso, colaboram no Programa inúmeros engenheiros agrônomos mexicanos, muitos dos quais já bastante especializados em suas funções.

\section{BIBLIOGRAFIA}

HARRAR, J. G. - Programa Agrícola Mexicano. Fundación Rockefeller, New York, 1950.

ROBERTS, L. M., E. J. WELLHAUSEN, G. PALACIOS de la ROSA y A. CUEVAS RIOS - Rocamex V-21 y Rocamex V5-101. Oficina de Estudios Especiales, S.A.G., 1949.

WELLHAUSEN, E. J. - El maiz hibrido y su utilización en Mexico. Of:cina de Estudios Especiales, S. A. G., 1951. 